\title{
Green Production of Indolylquinones, Derivatives of Perezone, and Related Molecules, Promising Antineoplastic Compounds
}

\author{
René Gerardo Escobedo-González, ${ }^{1}$ Héctor Pérez Martínez, ${ }^{1}$ Ma. Inés Nicolás-Vázquez, \\ Joel Martínez, ${ }^{2}$ Gabriela Gómez, ${ }^{3}$ Juan Nava Serrano, ${ }^{3}$ Vladimir Carranza Téllez, ${ }^{4}$ \\ C. L. Vargas-Requena, ${ }^{5}$ and René Miranda Ruvalcaba ${ }^{1}$
}

\author{
${ }^{1}$ Departamento de Ciencias Químicas, Facultad de Estudios Superiores Cuautitlán, Universidad Nacional Autónoma de México, \\ 54740 Cuautitlán Izcalli, MEX, Mexico \\ ${ }^{2}$ Facultad de Ciencias Químicas, Posgrado en Ciencias en Ingeniería Química, Universidad Autónoma de San Luis Potosí, \\ 78210 San Luis Potosí, SLP, Mexico \\ ${ }^{3}$ Escuela Nacional de Ciencias Biológicas, Instituto Politécnico Nacional, Casco de Santo Tomas, 11340 Ciudad de México, \\ CDMX, Mexico \\ ${ }^{4}$ Laboratorio de Espectrometría de Masas, Centro de Química, ICUAP, Benemérita Universidad Autónoma de Puebla, \\ 72570 Puebla, PUE, Mexico \\ ${ }^{5}$ Laboratorio de Biotecnología, Instituto de Ciencias Biomédicas, Universidad Autónoma de Ciudad Juárez, \\ Anillo Envolvente del Pronaf S/N, 32315 Ciudad Juárez, CHIH, Mexico
}

Correspondence should be addressed to René Miranda Ruvalcaba; mirruv@yahoo.com.mx

Received 4 May 2016; Accepted 14 June 2016

Academic Editor: Siva S. Panda

Copyright ( 2016 René Gerardo Escobedo-González et al. This is an open access article distributed under the Creative Commons Attribution License, which permits unrestricted use, distribution, and reproduction in any medium, provided the original work is properly cited.

\begin{abstract}
A green approach to produce the indolyl derivatives from four natural quinones (perezone, isoperezone, menadione, and plumbagin) was performed; in this regard, a comparative study was accomplished among the typical mantle heating and three nonconventional activating modes of reaction (microwave, near-infrared, and high speed ball milling or tribochemical), under solventless conditions and using bentonitic clay as a catalyst. In addition, the tribochemical production of isoperezone from perezone is also commented on. It is also worth noting that the cytotoxicity of the synthesized indolylquinones in human breast cancer cell was tested by 3-(4,5-dimethylthiazol-2-yl)-2,5-diphenyltetrazolium bromide assay, with the 3-indolylisoperezone being the most active. The structural attribution of the target molecules was performed by typical spectroscopic procedures; moreover, the experimental and computed ${ }^{1} \mathrm{H}$ and ${ }^{13} \mathrm{C}$ NMR chemical shifts data, with previous acquisition of the corresponding minimum energetic structures, were in good agreement.
\end{abstract}

\section{Introduction}

Green Chemistry, with a protocol of a cohesive set of twelve principles [1], is an actual discipline that encourages working at the molecular level, in order to achieve sustainability; since the early 1990s, this paradigm has acquired its up-to-date position as a scientific discipline, preventing pollution via the implementation of reactions without damaging conditions to the environment [2]. Under such a protocol, an ideal synthesis would be that by which a target molecule is produced quantitatively in one step from available and inexpensive starting compounds in an ecologically sustainable process; hence, the request of novel sustainable processes is among the major challenges in organic synthesis. In this regard, researchers at the vanguard of innovation must have the knowledge to design chemicals processes with little or no risk to the environment. However, no activity can be completely risk-free or waste-free or have lower harmful emissions. Consequently, the "Twelve Principles of Green Chemistry" should be viewed and applied as a scientific reflection [3].

Many quinones are secondary metabolites generally isolated from plants [4]. In particular, perezone or 
pipitzaoic acid, a sesquiterpene quinone, is recognized as the first secondary metabolite isolated in the New World by Río de la Loza [5], from the roots of Perezia (currently Acourtia) specimens; this important molecule has been the target of many chemical, structural, and biological studies, for example, its transformation into pipitzols [6-8] and isoperezone [9], its structural elucidation $[10,11]$, several green contributions [12], its use as a pigment [13], and highlighting several pharmacological effects [14-21]. By the way, plumbagin, a naphthoquinone from the genus Plumbago [22, 23], has been ascribed to several biological properties, for example, its antineoplasic activity [24].

In recent years, cancer prevention by means of natural products has received considerable attention; consequently, the chemistry of secondary metabolites is a powerful source for novel drug candidates. It is also convenient to underline the notion that the design and implementation of synthetic processes moving toward the Green Chemistry Protocol $[2,25]$ are one of the major challenges in modern organic synthesis.

The indolylquinone moiety is present in many natural products with interesting biological activities [26, 27]; consequently, the promising pharmaceutical use of the indolylquinones has attracted attention for the synthesis of new molecules of this class, mainly under a green approach. In this sense, the most common mode for the preparation of 3 -indolylquinones is the direct coupling of indole with several quinones, in the presence of a catalyst $\left(\mathrm{HCl}, \mathrm{H}_{2} \mathrm{SO}_{4}, \mathrm{AcOH}\right.$, $\mathrm{Bi}(\mathrm{OTf})_{3}, \mathrm{I}_{2}$, or $\mathrm{InBr}_{3}$ ) in the presence of solvent, using the mantle heating procedure in order to activate the reactions [28].

As part of our ongoing research program, we are interested in the implementation of green synthetic strategies, in order to synergize or modify the pharmacological activities of single known compounds throughout the construction of novel hybrid molecules, mainly using nonconventional activating sources such as microwave (MW) and near-infrared (NIR) irradiation, ultrasound (US), and high speed ball milling (HSBM) in the absence of solvent or using innocuous solvents [29-34] and when required employing Tonsil Actisil FF (TAFF), commercial bentonitic clay, as a green catalyst [35].

Taking into account the aforementioned commentaries, the goals of this work are, in a first stage, to offer a green contribution for the production of four pharmacologic candidates, the indolyl derivatives of perezone (1), isoperezone (2), menadione (3), and plumbagin (4), by comparison of typical mantle heating conditions $(\mathrm{MH})$ with uncommon activating modes, MW and NIR irradiation, in addition to the mechanical procedure of HSBM, all them in the absence of solvent and using TAFF as a catalyst. Additionally, we make an evaluation of the cytotoxic effect of the title molecules, in breast cancer cells as complement to theoretical-computation characterization of them. And finally, novel and convenient transformation of perezone into isoperezone, using for the first time HSBM, is also recommended.

\section{Materials and Methods}

General. The reagents indole and menadione were purchased from Sigma-Aldrich Chemical Co. and were used without further preparation. The secondary metabolites, perezone and plumbagin, were isolated from the vegetal specimens Acourtia adnata and Plumbago pulchella Boiss., respectively, according to literature procedures [36-39]. The reactions were monitored by thin layer chromatography (TLC) in $n$-hexane/ethyl acetate $(80: 20)$ using silica gel 60 $\mathrm{F}_{254}$ coated aluminum sheets; the corresponding visualization was achieved using a $254 \mathrm{~nm}$ UV lamp. The catalyst, Actisil FF (TAFF), bentonitic clay, was purchased from Tonsil Mexicana S.A. de C.V., Km 7 High Road, Puebla-Tlaxcala, Puebla, Mexico.

${ }^{1} \mathrm{H}$ and ${ }^{13} \mathrm{C}$ NMR spectra were performed using a Varian Mercury-300 spectrometer at $300 \mathrm{MHz}$ and $75 \mathrm{MHz}$ for hydrogen and carbon, respectively, employing $\mathrm{CDCl}_{3}$ as a solvent and TMS as an internal reference. The multiplicities are reported as singlet (s), broad singlet (bs), doublet (d), triplet $(\mathrm{t})$, and multiplet $(\mathrm{m})$. The EIMS and HRMS data were determined using JEOL JMS-700 MStation mass spectrometer. The elemental composition was calculated within a mass range of $\pm 10 \mathrm{ppm}$ from the accurate measured mass. The melting points were determined in a Fisher-Johns apparatus and are uncorrected. The microwave-assisted production of the target compounds was performed using CEM Focused Microwave ${ }^{\mathrm{TM}}$ Synthesis System. The near-infrared irradiation was generated using a commercial device "Flavor-Wave ${ }^{\circledR}$ " $(1300 \mathrm{~W} / 110 \mathrm{~V} / 120 \mathrm{~V}-60 \mathrm{~Hz} \mid 220 \mathrm{~V} / 240 \mathrm{~V}-60 \mathrm{~Hz})$ [45]. The high speed ball milling was generated using Ball Mill PM 100 Retch, with 6 carbon steel balls (weight: $23.85 \mathrm{~g}$, $0.39^{\prime \prime}$ diameter). The temperature was determined, for NIR, employing infrared thermometer (Infrared + Type K Thermometer, Extech Instruments, Sigma-Aldrich 2509388-1 EA); herein, the laser pointer was directed to the reaction center.

The human MDA-MB-231 breast cancer and dermal fibroblast normal cells lines were obtained from ATTC; $\mathrm{NaH}_{2} \mathrm{PO}_{4}$ and $\mathrm{Na}_{2} \mathrm{HPO}_{4}$ for phosphate buffer solution (PBS), 3-(4,5-dimethylthiazol-2-yl)-2,5-diphenyl tetrazolium bromide (MTT), and dimethyl sulfoxide (DMSO) were obtained from Sigma-Aldrich without further purification. The cells were cultured in Dulbecco's modified Eagle's medium (DMEM) supplemented with $10 \%$ fetal bovine serum (FBS), $100 \mathrm{U} / \mathrm{mL}$ penicillin $\mathrm{G}$, and $100 \mu \mathrm{g} / \mathrm{L}$ streptomycin in humidified atmosphere with $5 \% \mathrm{CO}_{2}$ at $37^{\circ} \mathrm{C}$. The culture medium was replaced every two days and the cells were used at passages between two and five. Statistical analysis of $\mathrm{IC}_{50}$ was executed by PRISMA statistical program.

The theoretical calculations were performed employing GAUSSIAN09 program [46].

2.1. Typical Experiments Using Thermal Conditions. A mixture of perezone $1(120 \mathrm{mg}, 0.4839 \mathrm{mmol})$, isoperezone 2 (120 mg, $0.4839 \mathrm{mmol})$, menadione 3 (90 $\mathrm{mg}, 0.5233 \mathrm{mmol})$ or plumbagin $4(140 \mathrm{mg}, 0.5000 \mathrm{mmol})$, indole $5(60 \mathrm{mg}$, $0.5128 \mathrm{mmol}$ ), and $50 \mathrm{mg}$ of TAFF as catalyst was placed in a micro scale glass vessel. The mixtures were treated using 
mantle heating during a period of $60 \mathrm{~min}$ at $95^{\circ} \mathrm{C}$. The reactions were monitored by TLC using silica gel $/ n$-hexane/ethyl acetate $(80: 20)$. The corresponding pure molecules were obtained by column chromatography using the same mobile phase as TLC.

\subsection{Typical Experiments Using Nonconventional Activating} Sources. A mixture of perezone $1(120 \mathrm{mg}, 0.4839 \mathrm{mmol})$, isoperezone $2(120 \mathrm{mg}, 0.4839 \mathrm{mmol})$, menadione $3(90 \mathrm{mg}$, $0.5233 \mathrm{mmol})$ or plumbagin $4(140 \mathrm{mg}, 0.5000 \mathrm{mmol})$, indole $5(60 \mathrm{mg}, 0.5128 \mathrm{mmol})$, and $50 \mathrm{mg}$ of TAFF as catalyst was placed in a micro scale glass vessel. The mixtures were treated using and comparing different activation modes: near-infrared irradiation during a period of $10 \mathrm{~min}$ at $121^{\circ} \mathrm{C}$; microwave irradiation during a period of $10 \mathrm{~min}$ at $100^{\circ} \mathrm{C}$ and $250 \mathrm{~W}$ power, and high speed ball milling during a period of $60 \mathrm{~min}$ with $500 \mathrm{rpm}$ and $27 \%$ power; all reactions were carried out in open vessel. The reactions were monitored by TLC using silica gel $/ n$-hexane/ethyl acetate $(80: 20)$. The corresponding products were purified by column chromatography using the same mobile phase as TLC.

2-Hydroxy-5-(1H-indol-3-yl)-6-methyl-3-(6-methylhept-5-en2-yl)cyclohexa-2,5-diene-1,4-dione (6). Purple solid; $\mathrm{mp}$ 65-67 $7^{\circ} \mathrm{C} .{ }^{1} \mathrm{H}$ NMR ( $\mathrm{CDCl}_{3} / \mathrm{TMS}$ ) ( $\left.\delta / \mathrm{ppm}\right): 8.905$ (bs, $1 \mathrm{H}$, $\mathrm{NH}), 8.250(\mathrm{~s}, 1 \mathrm{H}, \mathrm{OH}), 7.430\left(\mathrm{~d}, 1 \mathrm{H}, \mathrm{H}-7^{\prime}\right), 7.297(\mathrm{~d}, 1 \mathrm{H}$, $\left.\mathrm{H}-4^{\prime}\right), 7.225-7.162\left(\mathrm{~m}, 2 \mathrm{H}, \mathrm{H}-5^{\prime}, 6^{\prime}\right), 7.162\left(\mathrm{~s}, 1 \mathrm{H}, \mathrm{H}-2^{\prime}\right), 5.104$ (bs, 1H, H-12), 3.100-3.220 (m, 1H, H-8), 2.181 (s, 3H, H-7), 1.853-1.770 (m, 4H, H-10,11), 1.645 (s, 3H, H-14), 1.548 (s, 3H, $\mathrm{H}-15), 1.263$ (d, 3H, H-9). ${ }^{13} \mathrm{C} \mathrm{NMR} \mathrm{(CDCl} / 3$ TMS $)(\delta / \mathrm{ppm})$ : 187.00 (C-1), 184.70 (C-4), 151.10 (C-3), 140.30 (C-5), 135.90

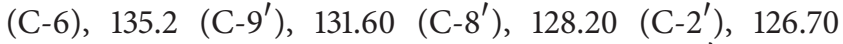
(C-13), 124.90 (C-12), 124.20 (C-2), 122.70 (C-6'), 120.90 $\left(\mathrm{C}-5^{\prime}\right), 120.80\left(\mathrm{C}-4^{\prime}\right), 111.90\left(\mathrm{C}-7^{\prime}\right), 108.90\left(\mathrm{C}-3^{\prime}\right), 34.50$ (C-10), 30.10 (C-8), 27.00 (C-11), 25.90 (C-14), 18.70 (C-9), 17.90 (C-15), 14.60 (C-7). EIMS (70 eV) $\mathrm{m} / z$ (\%): 363 (69) $\mathrm{M}^{+\bullet}, 348(6)[\mathrm{M}-15]^{+}, 334(7)[\mathrm{M}-29]^{+}, 281(100)[\mathrm{M}-82]^{+\bullet}$, 246 (6) $[\mathrm{M}-112]^{+\bullet}$. HRMS-EI $\mathrm{m} / z 363 \mathrm{M}^{+\bullet}$, calculated for $\mathrm{C}_{23} \mathrm{H}_{25} \mathrm{NO}_{3}: 363.1834 \mathrm{Da}$; found for $\mathrm{C}_{23} \mathrm{H}_{25} \mathrm{NO}_{3} 363.1816 \mathrm{Da}$ (-5 ppm error).

2-Hydroxy-5-(1H-indol-3-yl)-3-methyl-6-(6-methylhept-5-en2-yl)cyclohexa-2,5-diene-1,4-dione (7). Purple solid; $\mathrm{mp}$ 62-65 ${ }^{\circ} \mathrm{C} .{ }^{1} \mathrm{H}$ NMR $\left(\mathrm{CDCl}_{3} / \mathrm{TMS}\right)(\delta / \mathrm{ppm}): 8.476$ (bs, $1 \mathrm{H}$, $\mathrm{NH}), 8.100(\mathrm{~s}, 1 \mathrm{H}, \mathrm{OH}), 7.424\left(\mathrm{~d}, 1 \mathrm{H}, \mathrm{H}-7^{\prime}\right), 7.350(\mathrm{~d}, 1 \mathrm{H}$, $\left.\mathrm{H}-4^{\prime}\right), 7.26-7.128\left(\mathrm{~m}, 2 \mathrm{H}, \mathrm{H}-5^{\prime}, 6^{\prime}\right), 6.797\left(\mathrm{~s}, 1 \mathrm{H}, \mathrm{H}-2^{\prime}\right), 4.830$ (bs, 1H, H-12), 2.810-2.920 (m, 1H, H-8), 1.988 (s, 3H, H-7), 1.742-1.627 (m, 4H, H-10,11), 1.497 (s, 3H, H-14), 1.430 (s, 3H, $\mathrm{H}-15), 1.260$ (d, 3H, H-9). ${ }^{13} \mathrm{C}$ NMR $\left(\mathrm{CDCl}_{3} / \mathrm{TMS}\right)(\delta / \mathrm{ppm})$ : 188.00 (C-1), 183.70 (C-4), 151.40 (C-6), 149.60 (C-2), 135.70 $\left(\mathrm{C}-9^{\prime}\right), 132.30$ (C-13), 130.90 (C-8'), 128.20 (C-3), 123.80 (C-12), $122.80\left(\mathrm{C}-2^{\prime}\right), 122.60\left(\mathrm{C}-6^{\prime}\right), 120.90\left(\mathrm{C}-5^{\prime}\right), 120.40$ (C-4'), 116.50 (C-5), 114.10 (C-7'), 108.60 (C-3'), 38.70 (C-10), 30.36 (C-8), 29.00 (C-11), 23.98 (C-14), 23.01 (C-9), 14.09 (C-15), 11.12 (C-7). EIMS (70 eV) $\mathrm{m} / z$ (\%): $363(25) \mathrm{M}^{+\bullet}$, 348 (2) $[\mathrm{M}-15]^{+}, 279(28)[\mathrm{M}-84]^{+\bullet}, 261(100)[\mathrm{M}-102]^{+\bullet}$, 149 (90) $[\mathrm{M}-214]^{+\bullet}, 167(60)[\mathrm{M}-196]^{+\bullet}$. HRMS-IE: $\mathrm{m} / \mathrm{z}$
$363 \mathrm{M}^{+\bullet}$, calculated for $\mathrm{C}_{23} \mathrm{H}_{25} \mathrm{NO}_{3}: 363.1834 \mathrm{Da}$; found for $\mathrm{C}_{23} \mathrm{H}_{25} \mathrm{NO}_{3}: 363.1829 \mathrm{Da}$ (-1.5 ppm error).

2-(1H-Indol-3-yl)-3-methylnaphthalene-1,4-dione (8). Red dark solid, mp $123^{\circ} \mathrm{C} .{ }^{1} \mathrm{H}$ NMR $\left(\mathrm{CDCl}_{3} / \mathrm{TMS}\right)(\delta / \mathrm{ppm})$ : 8.800 (bs, $1 \mathrm{H}, \mathrm{NH}$ ), 8.220-8.120 (m, 2H, H-5,8), 7.800-7.740 (m, 2H, H-6,7), 7.456 (d, 1H, H-7'), $7.430\left(\mathrm{~s}, 1 \mathrm{H}, \mathrm{H}-2^{\prime}\right)$, 7.319 (d, $\left.1 \mathrm{H}, \mathrm{H}-4^{\prime}\right), 7.220-7.104\left(\mathrm{~m}, 2 \mathrm{H}, \mathrm{H}-5^{\prime}, 6^{\prime}\right), 2.213$ (s, $3 \mathrm{H}, \mathrm{H}-9) .{ }^{13} \mathrm{C}$ NMR (CDCl3/TMS) ( $\left./ \mathrm{ppm}\right): 186.00$ (C-1), 184.80 (C-4), 143.30 (C-2), 140.40 (C-3), $135.80\left(\right.$ C- $\left.^{\prime}\right), 133.50$ (C-7), 133.40 (C-6), 132.52 (C-10), 132.48 (C-11), 127.20 (C-8'), 126.70 (C-5), 126.20 (C-8), $122.30\left(\mathrm{C}-2^{\prime}\right), 120.40\left(\mathrm{C}-6^{\prime}\right), 120.30$ $\left(\mathrm{C}-5^{\prime}\right), 111.70\left(\mathrm{C}-4^{\prime}\right), 111.60\left(\mathrm{C}-7^{\prime}\right), 108.30\left(\mathrm{C}-3^{\prime}\right), 15.80(\mathrm{C}-9)$. EIMS $(70 \mathrm{eV}) m / z(\%): 287(30) \mathrm{M}^{+\bullet}, 270(100)[\mathrm{M}-17]^{+}, 269$ (12) $[\mathrm{M}-18]^{+\bullet}, 258(8)[\mathrm{M}-29]^{+}, 246(40)[\mathrm{M}-41]^{+}$. HRMS-EI: $m / z 287 \mathrm{M}^{+\bullet}$, calculated for $\mathrm{C}_{19} \mathrm{H}_{13} \mathrm{NO}_{2}: 287.0946 \mathrm{Da}$; found for $\mathrm{C}_{19} \mathrm{H}_{13} \mathrm{NO}_{2}: 287.0974 \mathrm{Da}$ (+9.8 ppm error).

5-Hydroxy-3-(1H-indol-3-yl)-2-methylnaphthalene-1,4-dione (9). Dark solid, mp $134-137^{\circ} \mathrm{C} .{ }^{1} \mathrm{H}$ NMR $\left(\mathrm{CDCl}_{3} / \mathrm{TMS}\right.$ )

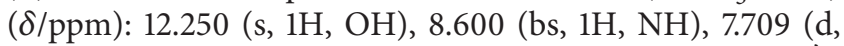
$1 \mathrm{H}, \mathrm{H}-8), 7.600-7.520(\mathrm{~m}, 1 \mathrm{H}, \mathrm{H}-7), 7.450\left(\mathrm{~d}, 1 \mathrm{H}, \mathrm{H}-7^{\prime}\right)$, $7.414\left(\mathrm{~s}, 1 \mathrm{H}, \mathrm{H}-2^{\prime}\right), 7.300$ (d, 1H, H-4'), 7.260-7.190 (m, $2 \mathrm{H}, \mathrm{H}-5^{\prime}, 6^{\prime}$ ), 7.200 (d, $\left.1 \mathrm{H}, \mathrm{H}-6\right), 2.196$ (s, 3H, H-9). ${ }^{13} \mathrm{C}$ NMR (CDCl $\left.{ }_{3} / \mathrm{TMS}\right)(\delta / \mathrm{ppm}): 189.87$ (C-4), 185.00 (C-1), 161.50 (C-5), 145.05 (C-2), 140.10 (C-3), 136.10 (C-9'), 135.70 (C-7), 132.50 (C-10), $126.90\left(\mathrm{C}-2^{\prime}\right), 126.50\left(\mathrm{C}-8^{\prime}\right), 123.90$ (C-6), 122.70 (C-6'), $120.70\left(\mathrm{C}-5^{\prime}\right), 120.30\left(\mathrm{C}-4^{\prime}\right), 118.90$ (C-8), 115.20 (C-11), 111.70 (C-7'), 107.90 (C-3'), 15.90 (C-9). EIMS $(70 \mathrm{eV}) \mathrm{m} / z$ (\%): $303(100) \mathrm{M}^{+\bullet}, 286(44)[\mathrm{M}-17]^{+}$, $274(20)[\mathrm{M}-29]^{+}, 186(8)[\mathrm{M}-117]^{+\bullet}$. HRMS-EI: $m / z 303$ $\mathrm{M}^{+\bullet}$, calculated for $\mathrm{C}_{19} \mathrm{H}_{13} \mathrm{NO}_{2}: 303.0895 \mathrm{Da}$; found for $\mathrm{C}_{19} \mathrm{H}_{13} \mathrm{NO}_{2}: 303.0873 \mathrm{Da}$ (-7.4 ppm error).

2.3. The 3-(4,5-Dimethylthiazol-2-yl)-2,5-diphenyl Tetrazolium Bromide Assay (MTT Assay). This test was performed with MDA-MB231 breast cancer cell line according to Mosmann [47]. Cells were incubated at different indolylquinone concentrations. To derive viability curves of 6-9 treated cells, the cells were seeded onto 96-well culture plate at density of 5000 cells/well and grown in DMEM supplemented with $10 \%$ FBS. Cells viability was measured using MTT reagent dissolved in PBS $(0.5 \mathrm{mg} / \mathrm{mL})$. On the day of measurement, the medium was carefully replaced by fresh DMEM $+10 \%$ FBS with diluted MTT $(1: 10,10 \%$ MTT $)$ and incubated for $1 \mathrm{~h}$ at $37^{\circ} \mathrm{C}$ in a $\mathrm{CO}_{2}$ incubator to allow the transformation of MTT dye to formazan salt. After removing incubation medium, formazan crystals were dissolved in $100 \mu \mathrm{L}$ solution of DMSO. It is also important to highlight the notion that MTT reduction was quantified by measuring the light absorbance at $570 \mathrm{~nm}$ using the Benchmark Plus absorbance microplate reader (Bio-Rad). MTT test was repeated nine times. Percentage of proliferation (\% viability) was calculated according to

$$
\% \text { viability }=\frac{B}{A} \times 100 \text {, }
$$


<smiles>CC(C)=CCCC(C)C1=C(O)C(=O)C(C)=CC1=O</smiles>

1<smiles>CC(C)=CCCC(C)C1=CC(=O)C(C)=C(O)C1=O</smiles>

2<smiles>CC1=CC(=O)c2ccccc2C1=O</smiles>

3<smiles>CC1=CC(=O)c2c(O)cccc2C1=O</smiles>

$\mathrm{MH}: 95^{\circ} \mathrm{C}, 60 \mathrm{~min}$, MW $250 \mathrm{w}, 100^{\circ} \mathrm{C}, 10 \mathrm{~min}$, NIR $121^{\circ} \mathrm{C}, 10 \mathrm{~min}$, HSBM 500 rpm, 60 min TAFF, solventless<smiles>c1ccc2[nH]ccc2c1</smiles><smiles>CC(C)=CCCC(C)C1=C(O)C(=O)C(C)=C(c2c[nH]c3ccccc23)C1=O</smiles>

6<smiles>CC(C)=CCCC(C)C1=C(c2c[nH]c3ccccc23)C(=O)C(C)=C(O)C1=O</smiles>

7<smiles>CC1=C(c2c[nH]c3ccccc23)C(=O)c2ccccc2C1=O</smiles><smiles>CC1=C(c2c[nH]c3ccccc23)C(=O)c2c(O)cccc2C1=O</smiles>

Scheme 1: Synthesis of indole-quinone derivatives.

where $A$ is the absorbance value of the control group and $B$ is the absorbance value of the cells treated with indolylderivatives.

2.4. $I C_{50}$ Determination. $\mathrm{IC}_{50}$ was extrapolated from the dose-response graph (Figure 1). The drug concentration that reduced the viability of cells by $50 \%\left(\mathrm{IC}_{50}\right)$ was determined by plotting triplicate data points over a concentration range and calculating values using regression analysis.

2.5. Computational Calculations. The reported calculations were carried out using Density Functional Theory (DFT) [48], employing Becke's three-parameter exchange and LeeYang-Parr correlation hybrid functional (B3LYP) $[49,50]$ with the $6-311++G(d, p)$ basis set including the split-valance and diffuse functions [51-53]. The corresponding quantummechanical calculations to determine the ${ }^{1} \mathrm{H}$ and ${ }^{13} \mathrm{C}$ chemical shifts were performed by Gauge-Invariant-Atomic Orbital method (GIAO method) [54].

\section{Results and Discussion}

3.1. Synthesis. The reactions of 1-4 with indole (5), under solventless conditions and with TAFF as a catalyst, were performed using the following three nonconventional modes of activation: microwave and near-infrared irradiation and high speed ball milling, affording the respective indole derivatives 6-9 (Scheme 1); in addition, the target molecules were comparatively obtained using mantle heating conditions; the corresponding results are summarized in Table 1.
TABLE 1: Production of indolylquinones derivatives, using different activating modes.

\begin{tabular}{lcccc}
\hline \multirow{2}{*}{ Product } & \multicolumn{4}{c}{ Yields \% } \\
& MH & MW & NIR & HSBM \\
\hline $\mathbf{6}$ & 24 & 79 & 62 & 24 \\
$\mathbf{7}$ & 12 & 35 & 31 & 18 \\
$\mathbf{8}$ & 46 & 42 & 51 & 30 \\
$\mathbf{9}$ & 25 & 41 & 64 & 35 \\
\hline
\end{tabular}

Best reaction conditions: $\mathrm{MH}, 95^{\circ} \mathrm{C}$ and $60 \mathrm{~min} ; \mathrm{MW}, 250 \mathrm{~W}, 100^{\circ} \mathrm{C}$, and $10 \mathrm{~min} ; \mathrm{NIR}, 121^{\circ} \mathrm{C}$ and $10 \mathrm{~min} ; \mathrm{HSBM}, 500 \mathrm{rpm}$ and $60 \mathrm{~min}$.

In general, the pathway must occur by classical Michael addition by the indol to the corresponding quinonic substrates, assisted by an interaction of the oxygen of a carbonylic group with the Lewis acidic sites of TAFF, followed by in situ oxidation, producing 6-9 in moderated yields at low times. It is appropriate to note that $\mathbf{6 , 7}$, and $\mathbf{9}$ are novel molecules, and according to our knowledge 8 has been previously produced by MH and US in the presence of solvent with the employment of a noninnocuous catalyst $[28,55,56]$. Moreover, literature research shows that this seems to be the first report for the green production of indolylquinones using MW, NIR, and HSBM as the activating modes without a solvent and in the presence of a natural ecofriendly catalyst.

A complementary and interesting result was the transformation of perezone into isoperezone, using for the first time HSBM (Scheme 2), in comparative yields and reaction times, with values previously reported $[9,12]$. 

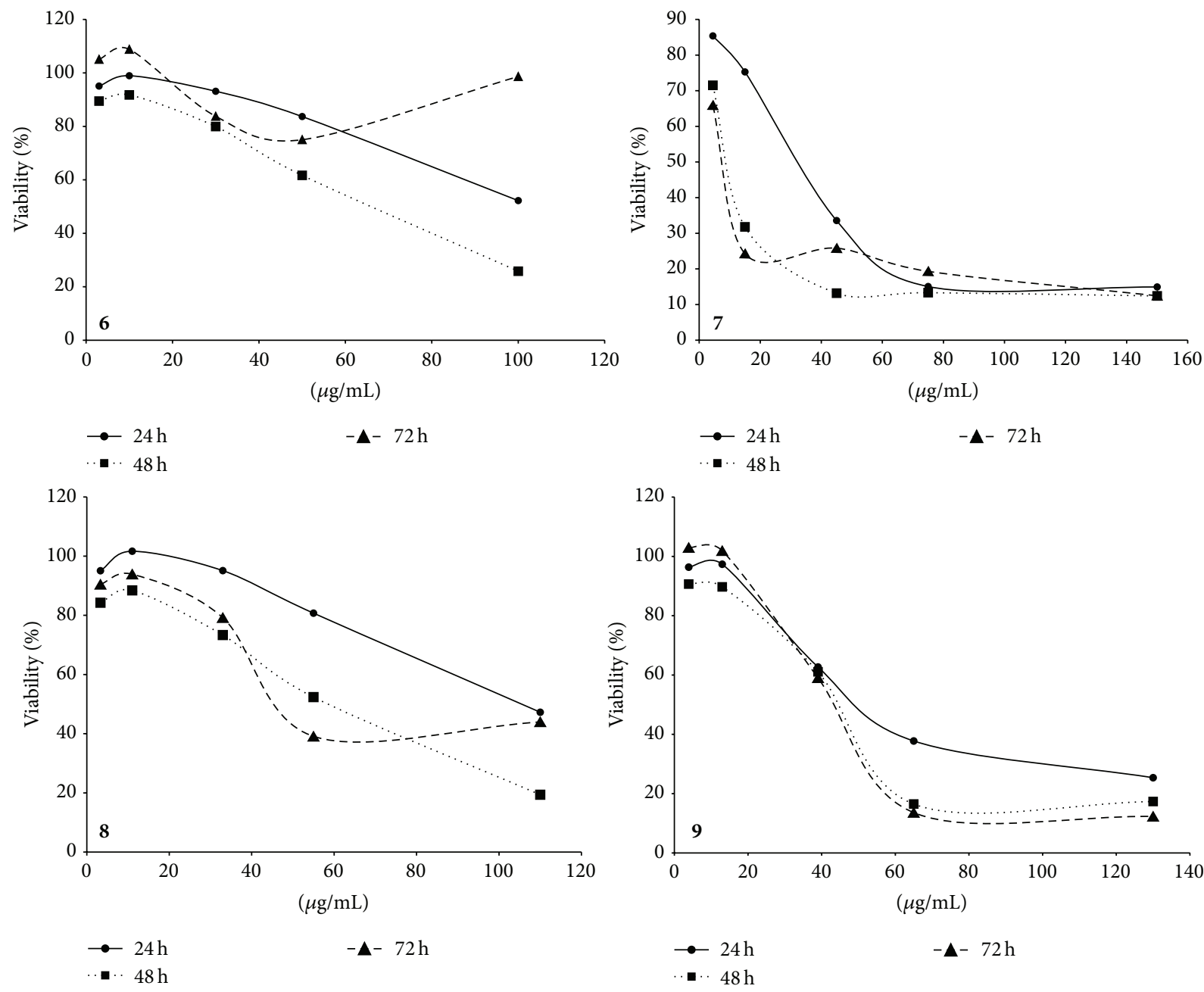

Figure 1: Dose-response graphs at 24, 48, and $72 \mathrm{~h}$ of $\mathbf{6 , 7 , 8}$, and 9.<smiles>CC(C)=CCCC(C)C1=CC(=O)C(C(C)CCC=C(C)C)=C(O)C1=O</smiles>

SCHEME 2: Transformation of perezone into isoperezone.

For the structural attribution of $\mathbf{2}$ and 6-9, in a first instance, isoperezone was spectroscopically correlated with literature data [9] as well as its melting point $\left(108-109^{\circ} \mathrm{C}\right)$. Considering the notion that $\mathbf{6 , 7}$, and $\mathbf{9}$ are novel products and that they are structurally related to $\mathbf{8}$, appropriate spectroscopic characterizations of the target molecules were performed. Thus, in a first place, the corresponding accurate molecular ions were acquired by HRMS-EI to achieve the elemental compositions; this was obtained in agreement with the expected products.

In regard to the ${ }^{1} \mathrm{H}$ NMR, it is worth noting the disappearance of the corresponding signals assigned to $\mathrm{H}-3$ of indole and reagents $\mathbf{2 - 4}$, in addition to the signal assigned to H-6 of perezone; moreover, the signal due to the proton linked to the nitrogen of the indole, $\delta 7.81 \mathrm{ppm}$, was displaced, for 6-9 to lower fields $8.4-8.9 \mathrm{ppm}$, unequivocally due to deprotection generated by the high degree of conjugation between the indolic-quinonic moieties of the products. In this sense, the obtained ${ }^{13} \mathrm{C}$ NMR data complemented the structural characterization of molecules 6-9, and the signals of C-3 and C-2 of indole at 102.22 ppm and 111.10 ppm were, respectively, displaced to lower fields, 107.9-108.9 and 122.3128.2 ppm, respectively. This change in the chemical shift was also attributed to deprotection by the quinonic system. In general, the ${ }^{1} \mathrm{H}$ and ${ }^{13} \mathrm{C}$ NMR experimental data correlated appropriately with those values predicted by computational models.

3.2. Cytotoxic Activity. Indolylquinones cytotoxicities were evaluated in human MDA-MB-231 breast cancer cells using the MTT assay, employing as control normal fibroblast cells. The studied compounds were assayed in concentrations of 0 to $100 \mu \mathrm{g} / \mathrm{mL}$ for 6,0 to $150 \mu \mathrm{g} / \mathrm{mL}$ for 7,0 to 110 for 8, and finally 0 to $130 \mu \mathrm{g} / \mathrm{mL}$ for $\mathbf{9}$. According to Figure 1, 


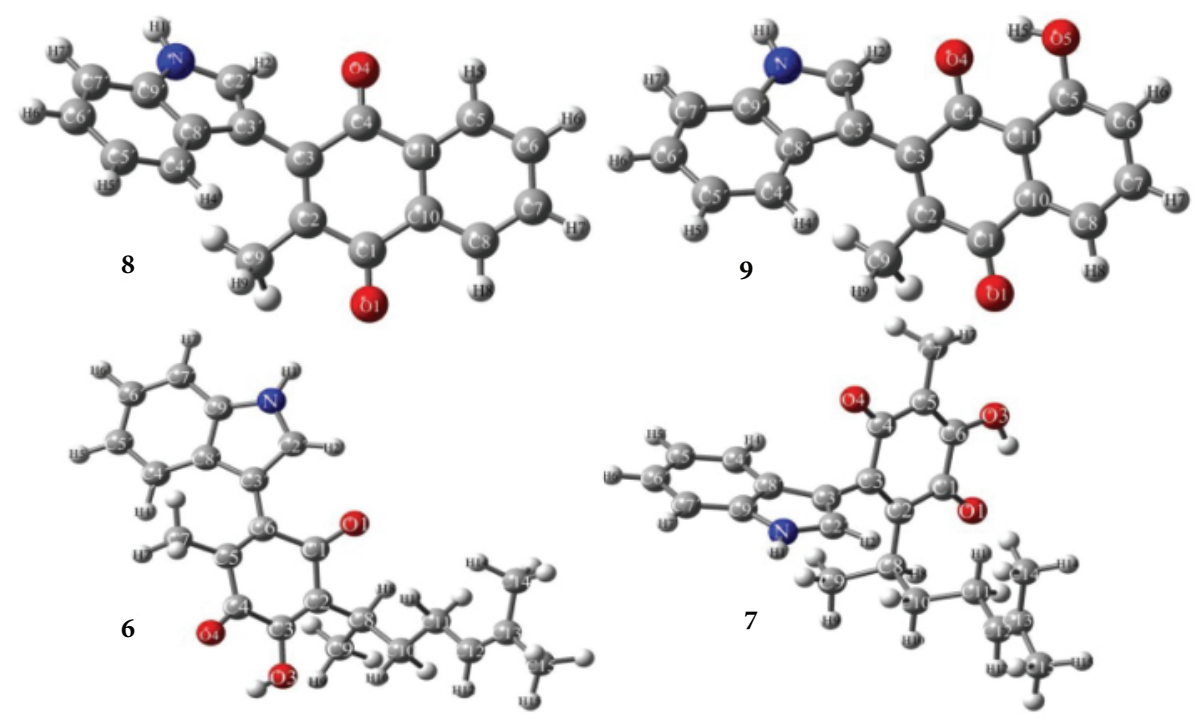

FIGURE 2: Optimized geometry of the indolylquinones through B3LYP/6-311++G(d,p).

the decrease of viable cells starts at 24 hours of incubation of the studied compounds; moreover molecule 7 began to decrease at a lower concenttration $(15 \mathrm{mg} / \mathrm{mL})$; on the other hand, for the rest of the molecules, the decrease of the viability began at concentrations higher than $20 \mu \mathrm{g} / \mathrm{mL}$. The same behavior was exhibited at $48 \mathrm{~h}$ with cancer cell viability in the range from 10 to $20 \%$ when the highest concentrations of 100 , 150,110 , and $130 \mu \mathrm{g} / \mathrm{mL}$ to $\mathbf{6}, \mathbf{7}, \mathbf{8}$, and $\mathbf{9}$, respectively, were used. The results after $72 \mathrm{~h}$ showed in 7 and 9 similar trends to those at $48 \mathrm{~h}$; however, 6 and $\mathbf{8}$ increased the cellular viability in the highest concentrations.

The $\mathrm{IC}_{50}$ values were obtained through extrapolation from the dose-response graphs (Figure 1). The results of the viability in human breast cancer cells against the four molecules tested recognize 7 as the most active molecule with $\mathrm{IC}_{50}$ of $25 \mu \mathrm{g} / \mathrm{mL}$. In addition, for $\mathbf{6}, \mathbf{8}$, and $\mathbf{9}$, the values of $\mathrm{IC}_{50}$ were $40.6,41.6$, and $32.3 \mu \mathrm{g} / \mathrm{mL}$, respectively. These concentrations were tested against healthy dermal fibroblast. With this result, it is important to point out that only 9 developed a cytotoxic effect with $15 \%$ mortality; on the other hand, 6-8, instead of promoting cells death, caused fibroblast proliferation. The effect in healthy cells is very interesting and is currently under study by our research group, as the cytotoxic pathway presented for these compounds.

3.3. Computational Study. The molecules obtained were also studied through computational chemistry methods. In the optimization of the target molecules, a conformer distribution and the selection of the most stable conformer were achieved. Additionally, the selected geometries were appropriately optimized by DFT employing B3LYP functional and the $6-311++G(d, p)$ basis set. The structures obtained in phase gas are depicted in Figure 2.

Molecular Geometries. The calculated geometrical parameters of 6-9 are displayed in Tables 2 and 3. Since the target molecules have no experimental X-rays partners and considering the important motif in the biological activities, the experimental data of the starter substrates and similar indol derivative present in the literature [40-42] was compared with the predicted value for the target molecules.

Table 2 shows the bond length of 6 and 7 by similar structure in both molecules. In the case of $\mathbf{6}$ compared with perezone quinonic ring, the predicted values are very similar to $\mathbf{1}$. However, the C1-C6 bond in $\mathbf{6}$ is longer in comparison with the perezone. Additionally, the hydrogen bond present between the $\mathrm{O} 3 \cdots \mathrm{H}$ hydroxyl group and the $\mathrm{O} 4$ carbonyl group decreases the distance, signaling a more stronger bond (intramolecular hydrogen bond); the $\mathrm{O} 3 \cdots \mathrm{O} 4$ and $\mathrm{H} 3 \cdots \mathrm{O} 4$ distances are 2.583 and $1.965 \AA$ beside $\mathrm{O} 3-\mathrm{H} 3 \cdots \mathrm{O} 4$ angle of $118.839^{\circ}$; these data agree with those of Soriano-García et al. [40]. Considering the indolyl moiety, the values were compared with the experimental values obtained for the Xray diffraction of 2-ethyl-5-(3-indolyl)oxazole [41].

The contrast of the indolyl fragment of $\mathbf{6}$ with the reference shows very similar values in both molecules; however, the predicted bonds are longer in $\mathbf{6}$.

The predicted values of $\mathbf{7}$ compared with the isoperezone show a similar trend in the quinonic ring; however, the bonds C3-C4 and C1-C6 are longer than in the experimental case. In the same sense, the intramolecular hydrogen bond is shorter, indicating the increase of the strength in this bond.

Regarding the indolyl moiety in 7 , the estimated values are in good agreement with the experimental values considering the structural difference between 7 and the 2-ethyl-5(3-indolyl)oxazole.

Table 3 summarizes some theoretical values of bond length for $\mathbf{8}$ and $\mathbf{9}$ contrasted with the X-rays values of $\mathbf{3}$ and $4[43,44]$ and the indolyl structure with 5-(3-indolyl) oxazole [41]. The calculated values for the bond C3-C4 of 8 and 9 are larger and the hydrogen bond of $\mathbf{9}$ is shorter following the same trends as the previous compounds ( 3 and $\mathbf{4})$. The rest of 
TABLE 2: Theoretical and experimental selected bond length (in angstrom) of 6 and 7.

\begin{tabular}{|c|c|c|c|c|}
\hline \multirow{2}{*}{ Bond } & \multicolumn{2}{|c|}{6} & \multicolumn{2}{|c|}{7} \\
\hline & Theoretical length & Experimental length & Theoretical length & Experimental length \\
\hline $\mathrm{C} 1-\mathrm{O} 1$ & 1.223 & $1.226^{\mathrm{a}}$ & 1.228 & $1.240^{\mathrm{c}}$ \\
\hline $\mathrm{C} 1-\mathrm{C} 2$ & 1.480 & $1.469^{\mathrm{a}}$ & 1.489 & $1.450^{\mathrm{c}}$ \\
\hline $\mathrm{C} 2-\mathrm{C} 3$ & 1.351 & $1.334^{\mathrm{a}}$ & 1.359 & $1.350^{c}$ \\
\hline $\mathrm{C} 3-\mathrm{C} 4$ & 1.494 & $1.498^{\mathrm{a}}$ & 1.523 & $1.490^{\mathrm{c}}$ \\
\hline C1-C6 & 1.527 & $1.469^{\mathrm{a}}$ & 1.491 & $1.430^{\mathrm{c}}$ \\
\hline $\mathrm{C} 3 / \mathrm{C} 6-\mathrm{O}$ & 1.343 & $1.347^{\mathrm{a}}$ & 1.340 & $1.250^{c}$ \\
\hline $\mathrm{C} 4-\mathrm{O} 4$ & 1.231 & $1.220^{\mathrm{a}}$ & 1.221 & $1.180^{\mathrm{c}}$ \\
\hline $\mathrm{C} 2-\mathrm{C} 8$ & 1.518 & $1.499^{\mathrm{a}}$ & 1.527 & $1.500^{\mathrm{c}}$ \\
\hline $\mathrm{C} 4-\mathrm{C} 5$ & 1.467 & $1.472^{\mathrm{a}}$ & 1.474 & $1.430^{\mathrm{c}}$ \\
\hline $\mathrm{C} 5-\mathrm{C} 7$ & 1.503 & $1.507^{\mathrm{a}}$ & 1.499 & $1.580^{c}$ \\
\hline $\mathrm{C}=\mathrm{O} \cdots \mathrm{H}$ & 1.965 & $2.340^{\mathrm{a}}$ & 1.985 & $2.650^{\mathrm{c}}$ \\
\hline $\mathrm{C} 5-\mathrm{C} 6$ & 1.362 & $1.332^{\mathrm{a}}$ & 1.348 & $1.390^{c}$ \\
\hline $\mathrm{C} 6 / \mathrm{C} 3-\mathrm{C}^{\prime}$ & 1.461 & $1.448^{\mathrm{b}}$ & 1.475 & $1.448^{\mathrm{b}}$ \\
\hline $\mathrm{C} 2^{\prime}-\mathrm{C} 3^{\prime}$ & 1.382 & $1.375^{\mathrm{b}}$ & 1.373 & $1.375^{\mathrm{b}}$ \\
\hline $\mathrm{C} 2^{\prime}-\mathrm{N}$ & 1.368 & $1.363^{\mathrm{b}}$ & 1.377 & $1.363^{\mathrm{b}}$ \\
\hline $\mathrm{C} 8^{\prime}-\mathrm{N}$ & 1.389 & $1.370^{\mathrm{b}}$ & 1.382 & $1.370^{\mathrm{b}}$ \\
\hline
\end{tabular}

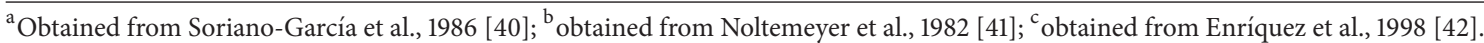

TABLE 3: Theoretical and experimental selected bond length (in $\AA$ ) of $\mathbf{8}$ and $\mathbf{9}$.

\begin{tabular}{|c|c|c|c|c|}
\hline \multirow{2}{*}{ Bond } & \multicolumn{2}{|c|}{8} & \multicolumn{2}{|c|}{9} \\
\hline & Theoretical length & Experimental length & Theoretical length & Experimental length \\
\hline $\mathrm{Cl}=\mathrm{O} 1$ & 1.223 & $1.229^{\mathrm{a}}$ & 1.223 & $1.228^{\mathrm{c}}$ \\
\hline $\mathrm{C} 1-\mathrm{C} 2$ & 1.494 & $1.453^{\mathrm{a}}$ & 1.491 & $1.451^{\mathrm{c}}$ \\
\hline $\mathrm{C} 2-\mathrm{C} 3$ & 1.363 & $1.366^{\mathrm{a}}$ & 1.365 & $1.306^{\mathrm{c}}$ \\
\hline $\mathrm{C} 3-\mathrm{C} 4$ & 1.503 & $1.484^{\mathrm{a}}$ & 1.498 & $1.470^{\mathrm{c}}$ \\
\hline $\mathrm{C} 3-\mathrm{C} 3^{\prime}$ & 1.471 & $1.448^{\mathrm{a}}$ & 1.467 & $1.448^{\mathrm{c}}$ \\
\hline $\mathrm{C} 4=\mathrm{O} 4$ & 1.219 & $1.231^{\mathrm{a}}$ & 1.240 & $1.229^{c}$ \\
\hline $\mathrm{C} 2-\mathrm{C} 11$ & 1.503 & $1.491^{\mathrm{a}}$ & 1.501 & $1.525^{\mathrm{c}}$ \\
\hline $\mathrm{C} 4-\mathrm{C} 10$ & 1.492 & $1.467^{\mathrm{a}}$ & 1.465 & $1.460^{\mathrm{c}}$ \\
\hline $\mathrm{C} 10-\mathrm{C} 5$ & 1.397 & $1.392^{\mathrm{a}}$ & 1.415 & $1.460^{\mathrm{c}}$ \\
\hline $\mathrm{C} 10-\mathrm{C} 9$ & 1.400 & $1.401^{\mathrm{a}}$ & 1.405 & $1.386^{\mathrm{c}}$ \\
\hline $\mathrm{C} 5-\mathrm{C} 6$ & 1.391 & $1.398^{\mathrm{a}}$ & 1.384 & $1.318^{\mathrm{c}}$ \\
\hline C6-C7 & 1.398 & $1.387^{\mathrm{a}}$ & 1.400 & $1.405^{\mathrm{c}}$ \\
\hline $\mathrm{C} 7-\mathrm{C} 8$ & 1.391 & $1.389^{\mathrm{a}}$ & 1.387 & $1.400^{c}$ \\
\hline $\mathrm{C} 8-\mathrm{C} 9$ & 1.397 & $1.398^{\mathrm{a}}$ & 1.410 & $1.364^{\mathrm{c}}$ \\
\hline $\mathrm{C} 9-\mathrm{Cl}$ & 1.488 & $1.479^{\mathrm{a}}$ & 1.49 & $1.492^{\mathrm{c}}$ \\
\hline C5-HO5 & - & - & 1.339 & $1.320^{\mathrm{c}}$ \\
\hline $\mathrm{C}=\mathrm{O} \cdots \mathrm{H}$ & - & - & 1.696 & $1.870^{\mathrm{c}}$ \\
\hline $\mathrm{C} 2^{\prime}-\mathrm{C} 3^{\prime}$ & 1.376 & $1.375^{\mathrm{b}}$ & 1.379 & $1.375^{\mathrm{b}}$ \\
\hline $\mathrm{C} 2^{\prime}-\mathrm{N}$ & 1.374 & $1.363^{\mathrm{b}}$ & 1.370 & $1.363^{\mathrm{b}}$ \\
\hline $\mathrm{C} 8^{\prime}-\mathrm{N}$ & 1.383 & $1.370^{\mathrm{b}}$ & 1.383 & $1.370^{\mathrm{b}}$ \\
\hline
\end{tabular}

a Obtained from Nowell and Attfield, 2004 [43]; bobtained from Noltemeyer et al., 1982 [41]; cobtained from Vijayalakshmi et al., 1987 [44].

the theoretical values are coherent and near the experimental values, appropriate with the theory level used.

The enlargement of the bonds C1-C6 (for 6 and 7) and C3-C4 (for 7, 8, and 9) in the quinonic rings and shortening in the intramolecular hydrogen bond $(6,7$, and 9$)$ can be explained by the resonance effect promoted by the addition of the indolic structure. The electrons of indole moiety can produce greater localization of electrons in the carbonyl group oxygen ( $\mathrm{C} 4=\mathrm{O} 4$ in $\mathbf{6}$ and $\mathrm{Cl}=\mathrm{O} 1$ in $\mathbf{7}, \mathbf{8}$, and 9) in contrast to 1-4 in which the double bonds of the quinone ring can be delocalized to both carbonyl groups. The consequence of this effect in 6-9 is the major negative charge in the oxygen 


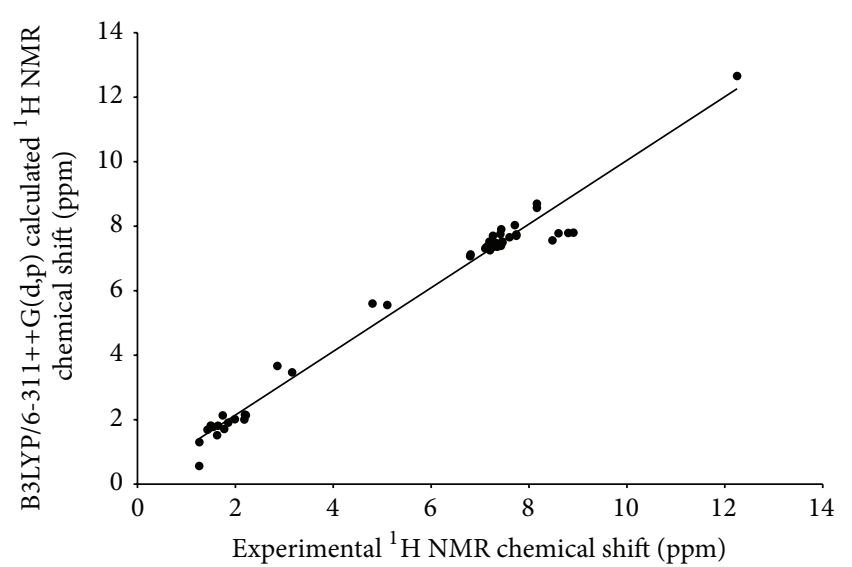

(a)

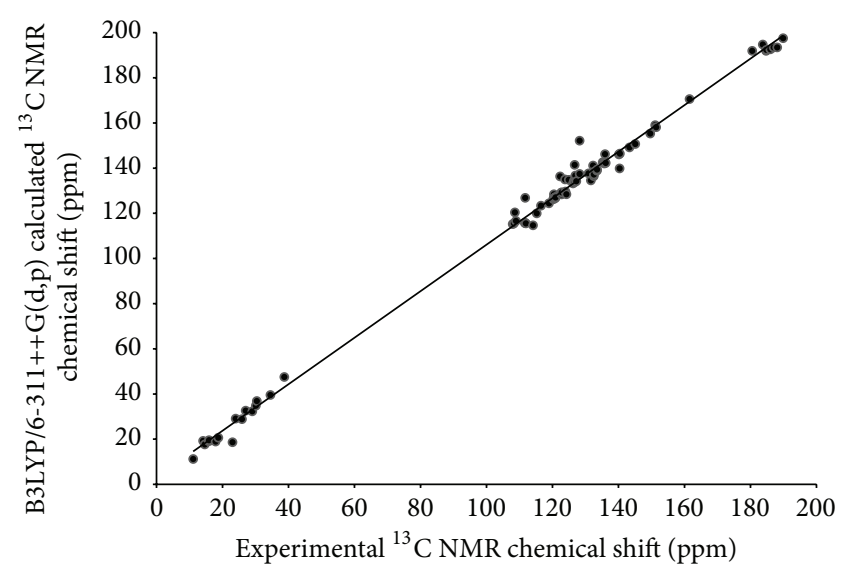

(b)

FIGURE 3: Linear regression between experimental and calculated B3LYP/6-311++G(d,p): (a) ${ }^{1} \mathrm{H}$ NMR chemical shifts and (b) ${ }^{13} \mathrm{C}$ NMR chemical shifts for the indolylquinones obtained in this work.

atom in the previous carbonyl group signaled and therefore greater attractive force to hydrogen and minor electronic delocalization to the bonds C1-C6 and C3-C4, provoking enlargement of these bonds.

NMR Parameters. The experimental values corresponding to the chemical shifts of ${ }^{1} \mathrm{H}$ and ${ }^{13} \mathrm{C}$ were correlated with the calculated values by DFT at the B3LYP and using the 6$311++\mathrm{G}(\mathrm{d}, \mathrm{p})$ basis set and the GIAO method.

The calculated GIAO ${ }^{1} \mathrm{H}$ NMR chemical shifts were plotted versus the experimental data obtained for the indolylquinones (Figure 3(a)).

Linear regression analysis of the data set of ${ }^{1} \mathrm{H}$ NMR shifts provided the following results and presented a regression coefficient of 0.9806 and standard deviation of $0.3930 \mathrm{ppm}$; the equation to describe the fit is $\delta_{T}=0.9875 \delta_{\mathrm{ex}}+$ $0.1661 \mathrm{ppm}$, where $\delta_{T}$ is a chemical shift predicted in the base of the experimental values $\delta_{\text {ex }}$, with the slope and intercept having a standard deviation of 0.0196 and 0.1261 , respectively.

The same analysis was made for the theoretical and experimental chemical shifts values obtained for ${ }^{13} \mathrm{C} N \mathrm{NM}$; the corresponding plot is shown in Figure 3(b); in this regard, the linear regression analysis for ${ }^{13} \mathrm{C}$ chemical shifts yielded a regression coefficient of 0.9955 and standard deviation of $3.35 \mathrm{ppm}$; the equation to describe the fit is $\delta_{T}=$ $1.0297 \delta_{\mathrm{ex}}+3.138 \mathrm{ppm}$, where the slope and intercept showed a standard deviation of 0.0076 and 0.937 , respectively.

In other words, the values of the regression coefficients in both analyses reflected a good description of the experimental chemical shifts of ${ }^{1} \mathrm{H}$ and ${ }^{13} \mathrm{C}$ NMR by the selected method, theory level, and basis set.

\section{Conclusions}

The methodology employed proceeded with a good green approach [57]; it is in agreement with the following Green Chemistry Principles: prevention (principle 1), atom economy (principle 2), less hazardous chemical synthesis (principle 3), safer solvents and auxiliaries (principle 5), design for energy efficiency (principle 6), catalysis (principle 9), and inherently safer chemistry for accident prevention (principle 12). In addition, it is convenient to note that the obtained molecules have a cytotoxic effect in breast cancer cells without apparently toxic effect in healthy cells, and the most cytotoxic molecule (7) corresponds to the minor gap energy (theoretical calculations); and it is also important to mention that the experimental activity will be explained on the base of theoretical studies under the course by our research group.

Finally, taking into account the fact that three of the molecules are new, appropriate spectroscopic characterizations were performed by means of ${ }^{1} \mathrm{H}$ NMR, ${ }^{13} \mathrm{C}$ NMR, EIMS, and HRMS, and it is important to highlight that the experimental NMR spectroscopic data of the target compounds showed good agreement with theoretical characterization.

\section{Competing Interests}

The authors declare that there are no competing interests regarding the publication of this paper.

\section{Acknowledgments}

The authors are mainly thankful to Grant PAPIIT UNAM IN221514-3, in addition to DGTIC-UNAM SC16-1-IR-27, and also René Escobedo and Joel Martínez acknowledge CONACyT-México 24992 for the Ph.D. scholarship and 205289 for the postdoctoral scholarship, respectively.

\section{References}

[1] P. T. Anastas and J. C. Warner, Green Chemistry: Theory and Practice, Oxford University Press, New York, NY, USA, 1998.

[2] P. T. Anastas and T. C. Williamson, Green Chemistry, Frontiers in Bening Chemical Synthesis and Processes, vol. 2, Oxford University Press, Oxford, UK, 1998. 
[3] J. Clark and D. Macquarrie, Handbook of Green Chemistry and Technology, Blackwell Science, Oxford, UK, 2002.

[4] G. P. Moss, Nomenclature of Quinones with Isoprenoid SideChains, Department of Chemistry, Queen Mary University of London, London, UK, 1973, http://www.chem.qmul.ac.uk/ iupac/misc/quinone.html.

[5] L. Río de la Loza, "Discurso pronunciado por el catedrático de química médica de la Escuela de Medicina (Noviembre 23, 1852)," in Escritos de Leopoldo Río de la Loza, J. M. Noriega, Ed., pp. 94-100, Imprenta de Ignacio Escalante, México City, Mexico, 1911.

[6] P. Joseph-Nathan, V. Mendoza, and E. García, "The chemistry of perezone and its consequences," in Studies in Natural Products Chemistry, Atta-ur-Rahman, Ed., vol. 5 of Structural Elucidation (Part B), pp. 763-813, Elsevier Science, Amsterdam, The Netherlands, 1989.

[7] I. H. Sánchez, R. Yáñez, R. Enríquez, and P. Joseph-Nathan, "A reaction mechanism change in the Lewis acid catalyzed perezone-pipitzol transformation," Journal of Organic Chemistry, vol. 46, no. 13, pp. 2818-2819, 1981.

[8] I. H. Sánchez, F. Basurto, and P. Joseph-Nathan, "The stereocontrol of the perezone to pipitzol transformation," Journal of Natural Products, vol. 47, no. 2, pp. 382-383, 1984.

[9] A. Rodríguez-Hernández, H. Barrios, O. Collera et al., "Isomerization of perezone into isoperezone and preparation of dihydroisoperezinone," Natural Product Letters, vol. 4, no. 2, pp. 133-139, 1994.

[10] E. Burgueño-Tapia and P. Joseph-Nathan, ${ }^{~}{ }^{13} \mathrm{C}$ NMR substituent chemical shifts in hydroxy-p-benzoquinones," Magnetic Resonance in Chemistry, vol. 38, no. 5, pp. 390-393, 2000.

[11] E. Burgueño-Tapia and P. Joseph-Nathan, "Detailed studies of perezone rearrangements," Monatshefte für Chemie, vol. 128, no. 6-7, pp. 651-658, 1997.

[12] J. Martínez, B. Velasco-Bejarano, F. Delgado et al., "Ecocontribution to the chemistry of perezone, a comparative study, using different modes of activation and solventless conditions," Natural Product Communications, vol. 3, no. 9, pp. 1465-1468, 2008.

[13] J. Arellano, F. Vázquez, T. Villegas, and G. Hernández, “Establishment of transformed root cultures of Perezia cuernavacana producing the sesquiterpene quinone perezone," Plant Cell Reports, vol. 15, no. 7, pp. 455-458, 1996.

[14] R. Enríquez, J. Ortega, and X. Lozoya, "Active components in Perezia roots," Journal of Ethnopharmacology, vol. 2, no. 4, pp. 389-393, 1980.

[15] F. J. Alarcon-Aguilar, R. Roman-Ramos, M. Jimenez-Estrada, R. Reyes-Chilpa, B. Gonzalez-Paredes, and J. L. Flores-Saenz, "Effects of three Mexican medicinal plants (Asteraceae) on blood glucose levels in healthy mice and rabbits," Journal of Ethnopharmacology, vol. 55, no. 3, pp. 171-177, 1997.

[16] A. L. De Peña, R. Izaguirre, G. Baños, M. Viveros, R. G. Enriquez, and J. M. Fernández-G, "Effect of perezone, aminoperezone and their corresponding isomers isoperezone and isoaminoperezone upon in vitro platelet aggregation," Phytomedicine, vol. 8, no. 6, pp. 465-468, 2001.

[17] E. Burgueño-Tapia, L. Castillo, A. González-Coloma, and P. Joseph-Nathan, "Antifeedant and phytotoxic activity of the sesquiterpene $p$-benzoquinone perezone and some of its derivatives," Journal of Chemical Ecology, vol. 34, no. 6, pp. 766-771, 2008.

[18] J. F. Téllez, K. Carvajal, D. Cruz, A. Cárabez, and E. Chávez, "Effect of perezone on arrhythmias and markers of cell injury during reperfusion in the anesthetized rat," Life Sciences, vol. 65, no. 16, pp. 1615-1623, 1999.

[19] L. E. Sánchez-Torres, J. A. Torres-Martínez, M. GodínezVictoria, J.-M. Omar, and B. Velasco-Bejarano, "Perezone and its isomer isoperezone induce caspase-dependent and caspaseindependent cell death," Phytomedicine, vol. 17, no. 8-9, pp. 614620, 2010.

[20] M. Concepción Lozada, O. Soria-Arteche, M. Teresa Ramírez Apan et al., "Synthesis, cytotoxic and antioxidant evaluations of amino derivatives from perezone," Bioorganic and Medicinal Chemistry, vol. 20, no. 17, pp. 5077-5084, 2012.

[21] R. G. Escobedo-González, L. Bahena, J. L. Arias Tellez, J. Hinojosa Torrés, R. M. Ruvalcaba, and J. M. Aceves-Hernández, "Characterization and comparison of perezone with some analogues. Experimental and theoretical study," Journal of Molecular Structure, vol. 1097, pp. 98-105, 2015.

[22] Y. Gou, Y. Zhang, J. Qi et al., "Binding and anticancer properties of plumbagin with human serum albumin," Chemical Biology and Drug Design, vol. 86, no. 3, pp. 362-369, 2015.

[23] W. Yan, B. Tu, Y. Liu et al., "Suppressive effects of plumbagin on invasion and migration of breast cancer cells via the inhibition of STAT3 signaling and down-regulation of inflammatory cytokine expressions," Bone Research, vol. 1, no. 4, pp. 362-370, 2013.

[24] D. Sajan, K. P. Laladhas, I. Hubert Joe, and V. S. Jayakumar, "Vibrational spectra and density functional theoretical calculations on the antitumor drug, plumbagin," Journal of Raman Spectroscopy, vol. 36, no. 10, pp. 1001-1011, 2005.

[25] P. Tundo, P. Anastas, D. S. C. Black et al., "Synthetic pathways and processes in green chemistry. Introductory overview," Pure and Applied Chemistry, vol. 72, no. 7, pp. 1207-1228, 2000.

[26] S. Koulouri, E. Malamidou-Xenikaki, and S. Spyroudis, "Acidcatalyzed addition of indoles to hydroxyquinones," Tetrahedron, vol. 61, no. 46, pp. 10894-10902, 2005.

[27] H.-B. Zhang, L. Liu, Y.-J. Chen, D. Wang, and C.-J. Li, "'On water'-promoted direct coupling of indoles with 1,4benzoquinones without catalyst," European Journal of Organic Chemistry, vol. 2006, no. 4, pp. 869-873, 2006.

[28] J. S. Yadav, B. V. S. Reddy, and T. Swamy, "Bi(OTf $)_{3}$-catalyzed conjugate addition of indoles to p-quinones: a facile synthesis of 3-indolyl quinones," Tetrahedron Letters, vol. 44, no. 51, pp. 9121-9124, 2003.

[29] R. Gómez, E. Ramírez-San Juan, R. Miranda et al., "Vasodilator effects of bis-dihydropyridines structurally related to nifedipine," Medicinal Chemistry, vol. 2, no. 5, pp. 527-534, 2006.

[30] B. Velasco-Bejarano, J. G. Trujillo-Ferrara, L. H. F. Castillo, R. Miranda, and L. E. Sánchez-Torres, "In vitro apoptotic activity of 2,2-diphenyl-1,3,2-oxazaborolidin-5-ones in L5178Y cells," Life Sciences, vol. 80, no. 11, pp. 1007-1013, 2007.

[31] M. O. Noguez, A. Garc, C. Ibarra, A. Cabrera, J. M. Aceves, and R. Miranda, "Green synthesis of bis-Biginelli esters, with vasodilatory effects, their mass spectrometric and physical studies," Trends in Organic Chemistry, vol. 13, pp. 75-82, 2009.

[32] L. Reyes, S. Corona, G. Arroyo, F. Delgado, and R. Miranda, "Eco-contribution for the production of $\mathrm{N}$-arylnitrones: solvent-free and assisted by microwaves," International Journal of Molecular Sciences, vol. 11, no. 6, pp. 2576-2583, 2010.

[33] J. Martínez, S. Romero-Vega, R. Abeja-Cruz, C. ÁlvarezToledano, and R. Miranda, "Green approach-multicomponent production of boron-containing Hantzsch and Biginelli esters," International Journal of Molecular Sciences, vol. 14, no. 2, pp. 2903-2915, 2013. 
[34] M. Zarco Juarez, J. O. Martínez, O. Noguez Cordova et al., "A green approach to the production of hybrid diindolylmethanephenylboronic acids via a 3MCR: promising antineoplasic molecules," Journal of Chemistry, vol. 2013, Article ID 531208, 9 pages, 2013.

[35] R. Miranda, H. Ríos, F. Delgado, M. Castro, A. Cogordán, and M. Salmón, "Characterization of a bentonitic clay and its application as catalyst in the preparation of benzyltoluenes and oligotoluenes," Applied Catalysis A: General, vol. 244, no. 2, pp. 217-233, 2003.

[36] F. Walls, M. Salmon, J. Padilla, P. Joseph-Nathan, and J. Romo, "La estructura de la perezona," Boletin del Instituo de Química de la Universidad Nacional Autónoma de Mexico, vol. 17, pp. 3-15, 1965.

[37] T. García, E. Domínguez, and J. Romo, "Aislamiento de la hidroxiperezona de Perezia alami," Boletin del Instituo de Química de la Universidad Nacional Autónoma de Mexico, vol. 17, pp. 16-18, 1965.

[38] M. A. Villavicencio and B. Perez-Escandon, "Actividad de la plumbagina (de Plumbago pulchella boiss: Plumbaginaceae) como siuasiva de la alimentación en tres especies de Orthopthera," Folia Entomológica Méxicana, vol. 86, 1992.

[39] M. A. Villavicencio and B. Perez-Escandon, "Concentración de plumbagina en Plumbago pulchella (Plumbaginaceae) y su efecto en la selección de alimento de larvas de Arachnis aulaea (Lepidoptera)," Folia Entomológica Méxicana, vol. 90, pp. 17-24, 1994.

[40] M. Soriano-García, R. A. Toscano, E. Flores-Valverde, F. Montoya-Vega, and I. López-Celis, "Structure of 2-(1,5dimethyl-4-hexenyl)-3-hydroxy-5-methyl-1,4-benzoquinone (perezone), a sesquiterpene," Acta Crystallographica Section C Crystal Structure Communications, vol. 42, no. 3, pp. 327-329, 1986.

[41] M. Noltemeyer, G. M. Sheldrick, H. U. Hoppe, and A. Zeeck, "2-Ethyl-5-(3-indolyl)oxazole from Streptomyces cinnamomeus discovered by chemical screening characterization and structure elucidation by X-ray analysis," Journal of Antibiotics, vol. 35, no. 5, pp. 549-555, 1982.

[42] R. G. Enríquez, J. M. Fernández-G, D. Gnecco, A. Pénicaud, and W. F. Reynolds, "The crystal and molecular structures of isoperezone, aminoperezone, and isoaminoperezone: a comparative study of their crystal packing," Journal of Chemical Crystallography, vol. 28, no. 7, pp. 529-537, 1998.

[43] H. Nowell and J. P. Attfield, "X-Ray and neutron powder diffraction studies of the crystal structure of vitamin $\mathrm{K}_{3}$," New Journal of Chemistry, vol. 28, no. 3, pp. 406-411, 2004.

[44] J. Vijayalakshmi, S. S. Rajan, and R. Srinivasan, "Structure of plumbagin," Acta Crystallographica Section C, vol. 43, no. 12, pp. 2375-2377, 1987.

[45] R. Escobedo, R. Miranda, and J. Martínez, "Infrared irradiation: toward green chemistry, a review," International Journal of Molecular Sciences, vol. 17, no. 4, p. 453, 2016.

[46] M. J. Frisch, G. W. Trucks, H. B. Schlegel et al., Gaussian 09, Revision D.01, Gaussian, Wallingford, Conn, USA, 2013.

[47] T. Mosmann, "Rapid colorimetric assay for cellular growth and survival: application to proliferation and cytotoxicity assays," Journal of Immunological Methods, vol. 65, no. 1-2, pp. 55-63, 1983.

[48] R. G. Parr and W. Yang, Density-Functional Theory of Atoms and Molecules, Oxford University Press, New York, NY, USA, 1989.
[49] A. D. J. Becke, "Density-functional thermochemistry. III. The role of exact exchange," The Journal of Chemical Physics, vol. 98, no. 7, pp. 5648-5652, 1993.

[50] C. Lee, W. Yang, and R. G. Parr, "Development of the ColleSalvetti correlation-energy formula into a functional of the electron density," Physical Review B, vol. 37, no. 2, pp. 785-789, 1988.

[51] P. M. W. Gill, B. G. Johnson, J. A. Pople, and M. J. Frisch, "The performance of the Becke-Lee-Yang-Parr (B-LYP) density functional theory with various basis sets," Chemical Physics Letters, vol. 197, no. 4-5, pp. 499-505, 1992.

[52] F. London, "Théorie quantique des courants interatomiques dans les combinaisons aromatiques," Journal de Physique et le Radium, vol. 8, no. 10, pp. 397-409, 1937.

[53] T. Clark, J. Chandrasekhar, G. W. Spitznagel, and P. V. R. Schleyer, "Efficient diffuse function-augmented basis sets for anion calculations. III. The $3-21+G$ basis set for first-row elements, Li-F,' Journal of Computational Chemistry, vol. 4, no. 3, pp. 294-301, 1983.

[54] M. Bühl, M. Kaupp, O. L. Malkina, and V. G. Malkin, "The DFT route to NMR chemical shifts," Journal of Computational Chemistry, vol. 20, no. 1, pp. 91-105, 1999.

[55] Y. Tanoue, T. Teraoka, N. Kai, T. Nagai, and K. Ushio, "Reaction of 3-iodoindole with 1,4-naphthoquinones," Journal of Heterocyclic Chemistry, vol. 47, no. 6, pp. 1447-1449, 2010.

[56] B. Liu, S.-J. Ji, X.-M. Su, and S.-Y. Wang, "Novel synthesis of 3-indolylquinones catalyzed by molecular iodine under ultrasonic irradiation," Synthetic Communications, vol. 38, no. 8, pp. 1279-1290, 2008.

[57] M. Morales, J. Martinez, L. Reyes-Sánchez et al., "How green experiment is?” Educación Quimica, vol. 22, pp. 240-248, 2011. 

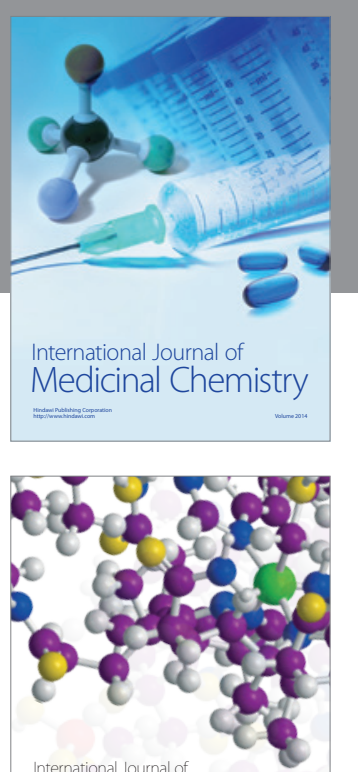

Carbohydrate Chemistry

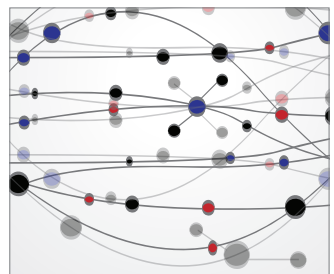

The Scientific World Journal
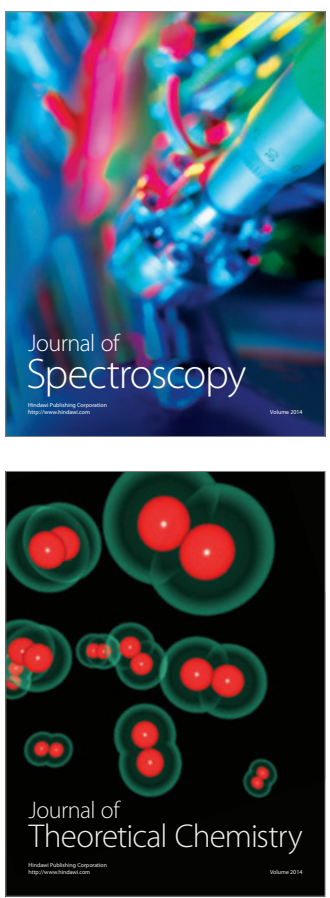
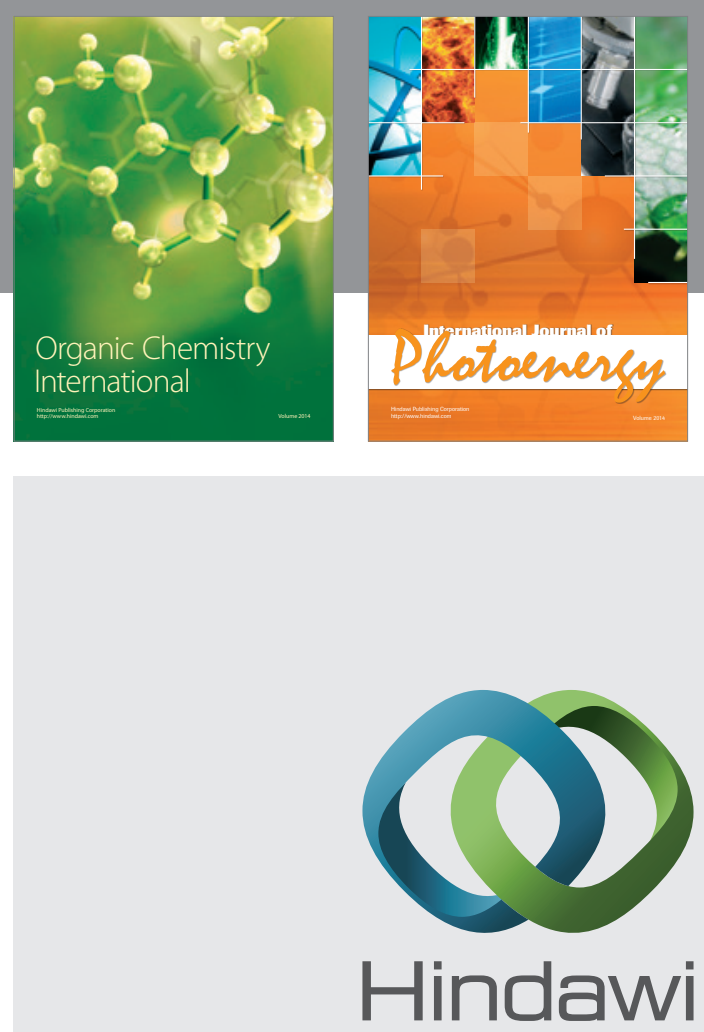

Submit your manuscripts at

http://www.hindawi.com

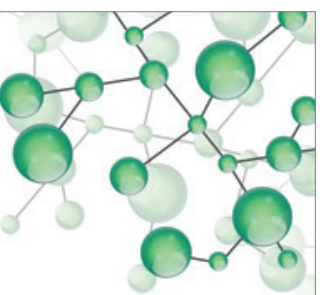

International Journal of

Inorganic Chemistry

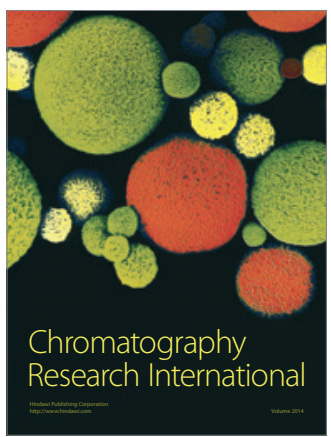

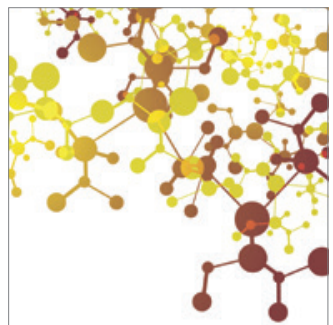

Applied Chemistry
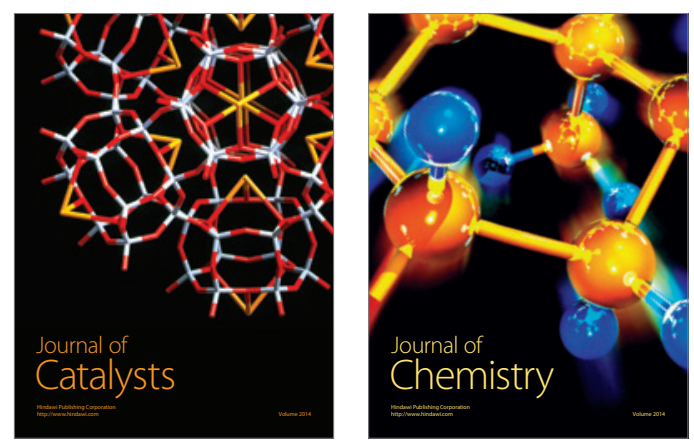
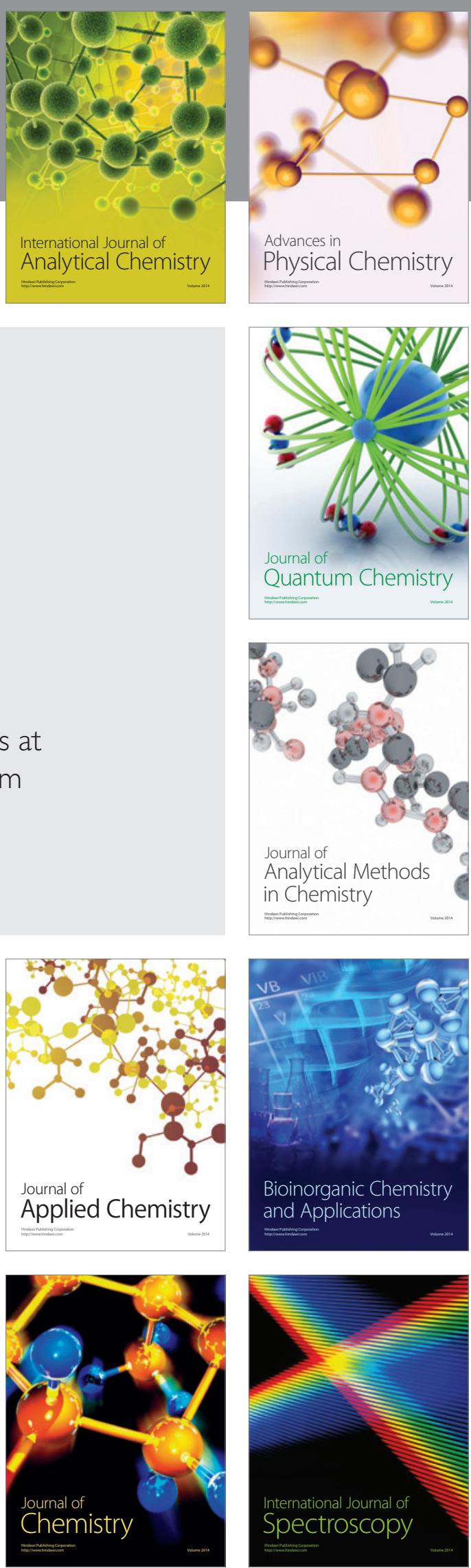